This is an electronic reprint of the original article. This reprint may differ from the original in pagination and typographic detail.

Author(s): Lähdesmäki, Tuuli

Title: $\quad$ The Inclusion and Exclusion of Europe as a Discursive Strategy in Populist Political Rhetoric

Year: $\quad 2014$

Version:

Please cite the original version:

Lähdesmäki, T. (2014). The Inclusion and Exclusion of Europe as a Discursive Strategy in Populist Political Rhetoric. In S. Marino (Ed.), Interdisciplinary Perspectives and Trajectories on Pluralism, Inclusion and Citizenship (pp. 29-43). Inter-Disciplinary Press.

All material supplied via JYX is protected by copyright and other intellectual property rights, and duplication or sale of all or part of any of the repository collections is not permitted, except that material may be duplicated by you for your research use or educational purposes in electronic or print form. You must obtain permission for any other use. Electronic or print copies may not be offered, whether for sale or otherwise to anyone who is not an authorised user. 


\title{
The Inclusion and Exclusion of Europe as a Discursive Strategy in Populist Political Rhetoric
}

\author{
Tuuli Lähdesmäki
}

\begin{abstract}
In recent decades global cultural flows and the movement of people within and across the borders of the EU have diversified Europe by increasing the inner pluralism of European societies. At the same time European societies have faced the rise of diverse nationalist and populist movements and political parties. These movements and parties have criticized the increasing diversity in Europe, finding faults especially in the EU integration process, current immigration policies, and the consequent development of multi- and intercultural societies. In current populist discourse, 'borderlessness' and the transformation of the current cultural, symbolic, and societal borders are often objected or perceived as a threat to the 'right' or traditional order. Europe is a profoundly flexible concept and, in Ernesto Laclau's terms, a 'floating signifier' which can be given various meanings depending on the speaker's political aims. In populist discourse, Europe as a cultural, political, economic, spatial, symbolic, and moral concept often comprises contradictory meanings. On the one hand, Europe can be perceived as a cultural and value-based community, which shares a common history, (Christian) heritage, and similar values and moral norms. In populist discourse, identification with Europe and the promotion of it as a cultural and value community is particularly pronounced when a threat towards 'us' is experienced as coming from outside the imagined European borders. On the other hand, Europe as a political project and the political and cultural integration in Europe can be articulated as a threat to national independence, identity, and cultural particularity. In my chapter, I will analyse the meaning-making of the idea of Europe and its flexibility in current populist political discourse in Finland. The empirical focus of the chapter is in the Finns Party and the political rhetoric found in its party newspaper.
\end{abstract}

Key Words: Discourse, Europe, the European Union, Finland, identity, nationalism, populism, the Finns Party.

\section{Introduction}

In recent decades, global cultural flows and the movement of people within and across the borders of the EU have diversified Europe by increasing the inner pluralism of European societies. As a reaction to the increased pluralism, the recent cultural, societal, and political changes, and the way different kinds of threats to them are disseminated for public imagination by the media, European societies have faced the rise of diverse nationalist movements and populist political parties. 
These movements and parties have criticized the increasing diversity in Europe, finding faults especially in the EU integration process, current immigration policies, and the consequent development of multi- and intercultural societies. The agendas and attempts of the populist parties have often centred around creating or maintaining borders and rejecting different kinds of threats which are considered to be the result of increasing 'borderlessness' of societies and cultures. One of the main concerns of the populist parties in Europe, such as The Finns Party, National Front (France), Vlaams Belang (Belgium), Sweden Democrats, Jobbik (Hungary), UKIP (Britain), Freedom Party of Austria, etc., is the weakening of the particularity of nations, their national cultures, and the independence of nationstates. This weakening is related to the EU integration policies and the consequences of the extra-EU immigration, which is considered a threat not only to the national particularity but also to the European cultural communality. In the discourse of populist parties, the relationship with 'Europe' is profoundly complex and includes contradictory and flexible situational meanings: the meanings differ drastically depending on the context in which Europe is been discussed.

The rise of 'new' nationalism in Europe at the end of the 20th century has been much discussed in the academia. On the one hand, scholars have pointed out how supranational structures, transnational interaction, globalization, and the increased 'creolization, ${ }^{1}$ of culture have caused a backlash of national and ethnic sentiments and of territorial attachments and activated interest in fostering and searching for regional and national cultural roots and traditions. ${ }^{2}$ On the other hand, non-statebased forms of identification, such as the identification with Europe $^{3}$ and constitutional patriotism, ${ }^{4}$ have been considered to replace state-based nationalism. In these discussions, identity has been theorised as a 'thin' civic or political identity formed e.g., on the basis of legal rights, citizenship statuses, constitutions, economic networks, or the functional cooperation of administrative units. As a consequence of these diverse trajectories, different kinds of identity projects and political movements and discourses related to their promotion have polarized and are getting more pronounced expressions and manifestations.

The rise of 'new' nationalism in Europe is closely related to the challenge of the current socio-political order, which is considered to be characterized by the blurring of the right/left-dualism and the naturalization of the (neoliberal) 'thirdway consensus'. ${ }^{5}$ The pro-European/EU politics and the promotion of an image of 'new' Europe as a peace project are crucial elements in the creation of the political consensus in European societies. ${ }^{6}$ The challenge of both this consensus and the current socio-political order is manifested in diverse populist attempts, which are fuelled by the invisible (i.e., covered by the consensus) but existing antagonist split in contemporary politics. ${ }^{7}$ Instead of a right/left-dualism, this antagonism is usually articulated through the distinction between 'right' and 'wrong', or in the moral register through the categories of 'good' and 'evil'. 
In my chapter, I will analyse the discursive meaning-making of the idea of Europe and its flexibility as a 'floating signifier' in current populist political discourse in Finland. The empirical focus of the chapter is in the Finnish party Perussuomalaiset (The Finns Party) and the political rhetoric in its party newspaper Perussuomalainen. The party was established in 1995 and it has increased its popularity in each parliamentary election gaining a major victory in 2011 by receiving $19.05 \%$ of the vote. The party can be characterized as nationalistpopulist: both terms are used in a positive meaning in the party programs and the writings of the party leader Timo Soini. ${ }^{9}$ Their agenda is a mixture of traditionally left-wing social and income distribution politics, right-wing value conservatism, and an explicit national emphasis. The party has offered a eurosceptical alternative in the Finnish political climate, which has been considered to have an overly consensual style and lack an elite-level opposition to the European integration process. ${ }^{10}$ The agenda of Perussuomalaiset draws together protests against various faults found in the society, thus bringing together politicians with diverse interests and views. ${ }^{11}$ Therefore, several complex and ambiguous concepts and entities, such as 'Europe', are used in the political rhetoric of the party in diverse ways in order to justify the views and attempts of the speaker considering a particular matter.

The data consists of texts published in the party newspaper Perussuomalainen between 1 January 2004 and 2 July 2013. During the data collection, all the texts were searched for the headwords the EU, Europe, nation, identity, and/or culture. After a pre-read, 478 texts were selected as the corpus because they contained deeper discussion on the headwords. The key results of the qualitative content analysis on the meanings of Europe in the corpus are presented in section four.

\section{Populism and the Use of 'Floating Signifiers'}

Populism has been investigated in various fields, such as political studies, discourse studies, cultural studies, and socio-psychology, and approached from various perspectives, e.g., as a movement, a form of rhetoric, a political style, a type of ideology, ${ }^{12}$ a political strategy, ${ }^{13}$ a means for mobilization, ${ }^{14}$ and a social logic. ${ }^{15}$ Several scholars have emphasized the ambivalent nature of populism - it does not have a solid core or a common ideology. ${ }^{16}$ There are several types of populism and particular cultural, historical, and political contexts frame the contents and the main areas of interest in their ideologies. In spite of the ambiguity of the concept and the diverse points of view to approach it, there is currently much less controversy over how to define populism than before, as Agnes Akkerman, Cas Mudde, and Andrej Zaslove have noted. ${ }^{17}$ According to them, populism is a

thin-centred ideology that considers society to be ultimately separated into two homogeneous and antagonistic groups, 'the pure people' versus the 'corrupt elite,' and which argues that 
politics should be an expression of the volonté générale (general will) of the people. ${ }^{18}$

As a 'thin-centred' ideology, populism rarely exists on its own; it mostly attaches itself to other ideologies ranging from the radical right to socialism, etc. ${ }^{19}$

Several scholars, such as Ernesto Laclau, have emphasized the importance of rhetoric for populism: rhetoric constructs and mobilizes the populist movements and is thus performative and functional. ${ }^{20}$ Populist rhetoric is often described as relying on an affective, emotive, and metaphoric language; polarization; simplification; stereotypification; vague expressions; perceiving threats, faults, and enemies; and appeals to 'cultural commonplaces ${ }^{, 21}$ (i.e., shared physical places or more abstract sentimental areas of cultural meanings which need no justification and cannot be rationalized). The 'discourse of people' forms the core of populism and its rhetorical strategies. ${ }^{22}$ However, the notion of people in the discourse is profoundly flexible and can be used in various meanings referring e.g., to 'men from the street'; 'us' and 'our' people who share common experiences, history, language, and culture; or people who live in the same state and form the nation. ${ }^{23}$ In all meanings, the 'discourse of people' either explicitly or implicitly constructs the idea of nation. The discourse appreciates the traditional lifestyle and aims to rediscover and protect the 'own' culture of the people. ${ }^{24}$

In the rhetoric of populism, the people and the nation are often defined through their discursive antitheses, such as elites, bureaucrats, politicians, immigrants, foreigners, the EU, and Europe. The meanings of these negations are also flexible and fluid and constructed in the 'discourse of people'. Ernesto Laclau and Chantal Mouffe - scholars who have investigated populism in the field of political science from the perspective of poststructuralist discourse theory - have defined a discourse as an attempt to fix a web of meanings within a particular domain. This attempt involves the structuring of signifiers into certain meanings in order to exclude other meanings. ${ }^{25}$ Laclau refers to the elements that are particularly open to different ascriptions of meaning as 'floating signifiers' ${ }^{26}$ Floating signifiers have different connotations depending on the discourse in which they are used. They are open to continual contestation and articulation to different political projects. ${ }^{27}$ Thus, the attempts to fix the meanings of floating signifiers can be seen as an exercise of power and the politics of populism.

\section{Theorizing European Identity}

In recent studies, the idea of Europe and European identity have been approached from a social constructionist point of view, laying emphasis on the use of language, rhetoric, narration, and discursive practices as locations in which their meanings are both consciously and unconsciously produced. ${ }^{28}$ As the studies indicate, Europe and European identity are profoundly ambiguous notions and 
include meanings, which vary depending on the discursive situations in which they are produced, defined, and used.

Both academic and political discussions on Europe and European identity are often characterized by a varying emphasis on the interpreted unity or diversity of cultures in Europe. ${ }^{29}$ The discussions stressing unity often rely on the idea of common cultural roots, history, heritage, and values as a concrete base for coherence in Europe. These discussions bring to the fore the notion on European identity as a 'thick' cultural identity based on (real or imagined) shared cultural features. In the discussions emphasizing diversity, culture is not considered as a common source for European identity nor given the role of a unifier or a determinant of Europe. Instead, a variety of cultures and their plurality are considered as a key characteristic of Europe. Discussions emphasizing the diversity in Europe approach European identity as a 'thin' civic or political identity, formed e.g., on the basis of legal rights, citizenship statuses, constitutions, economic networks, or the functional cooperation of administrative units. ${ }^{30}$

Several scholars have criticized the cultural determination of Europe by bringing to the fore how culture has become a site for new conflicts over identity politics in Europe ${ }^{31}$ and how outlining Europeanness in cultural terms has led to racist and xenophobic demarcations and discourses. ${ }^{32}$ However, the civic/political dimension of European identity emphasized by some views has been criticised as too insufficient and abstract for shaping a common identity. ${ }^{33}$ The EU has aimed to combine in its political rhetoric both the unity and diversity as the key features of European identity. These attempts have however been criticized as a mere formal solution that enables a new version of Eurocentric triumphalism. ${ }^{34}$

Identity formations are often produced by distinguishing oneself and one's 'own' group from the 'others' and by articulating a presupposed 'constitutive outside'. ${ }^{35}$ Throughout history, the ideas of Europe and common European identity have often been formulated using diverse negations of the continent and by invoking its common threats - whether they are the Turks, the Russians, American or Asian economic powers, or Islam. ${ }^{36}$ On the one hand, Europe and European identity can be perceived as being produced as a negation of or a reaction to a 'non-Europe'. On the other hand, the 'other' can also be found within the borders of Europe. ${ }^{37}$ In the discourse promoting European integration, nations and nationalism function as counter-powers to Europe - and respectively in the nationalist discourse, the idea of a united Europe forms a threat that needs to be rejected.

\section{Meanings of Europe in the Newspaper of The Finns Party}

In the corpus, the meanings of Europe are rhetorically fixed to diverse threats and key populist dichotomies. When Europe is paralleled with the EU, it is represented as a threat to the common people in Europe, European nations, national independence and cultures, democracy, and the state of law. When a threat is 
located outside Europe, its target is the European civilization, Christianity, current order in Europe, and the common European culture, heritage, values, and mentality. Europe is thus both a threat to its citizens and threatened by the outsiders. The 'EU-Europe' represents three key dichotomic enemies in the rhetoric of populism: the political elite, bureaucrats, and the rich. The EU and all kinds of integration processes in Europe are perceived as projects of the rich political elite dominating or ignoring the poor and powerless common people. Thus, the meanings of the EU-Europe are intertwined with manifold power relations and hierarchies of dominance and subordination.

The ideas of nation and nation-state form the fundamental basis for the articulation of Europe in the corpus. Europe is signified as 'Europe of nations' and 'Europe of nation-states': a geographical location of distinct ethnic nations demarcated by their national culture and state-borders. The nation, its national culture, the 'fatherland', the state independence, and democracy form a strong rhetorical unity, which represents everything that Europe is seen as lacking. In the corpus, the EU is not perceived as a transnational political agent, but approached through the idea of nation-state. Therefore the EU-Europe is seen both as an impossible construction (because it lacks the key characteristics of a nation) and a threat to 'real' nation-states because of its attempts to establish a new nation-state that would replace the old ones.

Even though the interaction between distinct nation-states in Europe is usually considered positive in the corpus, the trans-European cooperation under the EU policies and programs is negatively determined. Supranational, transnational, or multinational structures are considered as threats to a fundamental and 'natural' political unit: the nation-state. Transnationalism is rhetorically related to various kinds of negatively charged mingles of 'pure' entities and threats of borderlessness. In addition, transnationalism in the EU-Europe is attacked in the corpus with undemocratic, disloyal, and quarrelsome tones: the EU forces the nation-states to trans-European interaction, and causes an unwanted transnational battle in which the bigger, impudent nation-states are considered as selfishly scooping benefits.

In the rhetoric of the corpus, the unfamiliar and threatening 'Europe's other' takes various forms: it is distinguished in spatial, cultural, religious, social, and temporal terms. When the 'other' is located outside European borders, it is often referred to in religious terms. 'Islam' is defined as a negation of Europe representing not only the antithetic religion but also the contrary cultural, mental, and moral norms - which in the rhetoric of the corpus are closely intertwined with religion. In these views, 'Islam' and 'Europe' (or 'the West') are seen as two coherent entities that have their own original spatial homes. In the rhetoric of the corpus, religion is thus culturalised, territorialised, and outlined as an essentialist source of identity for the people within these territories. In the corpus, some writers brought to the fore evolutionist views on the battle of civilizations, in which Europe was perceived as being threatened by immigration, multiculturalisation, 
and islamisation and as being profoundly vulnerable due to its secularised, proimmigration-minded, and (over) liberal current state. Defending Europe against these threats outlined it as a cultural entity, in which the (original European) people share a common cultural heritage, mentality, sense of justice, and Christian morals and ethics.

As several scholars have noted, 'Europe's other' is often searched for from outside its territorial borders, even though it can be distinguished in time rather than space. ${ }^{38}$ In the pro-European discourses and the official EU policy rhetoric, the European integration is often justified by appealing to the prevention of the recurrence of Europe's warlike history, particularly the horrors of the WWII. In the rhetoric found in the corpus, history is also used as a warning example for contemporary Europe, but from an opposing point of view. In the texts, the EU and European integration are paralleled with the Soviet Union and its undemocratic decision-making and authoritarian and oppressive politics.

In addition to the extra-European and temporal dimension, the texts in the corpus define 'Europe's other' in social terms. Europe is not only threatened by the poor immigrants coming from outside its borders, but also by the poor, underdeveloped, and corrupted states in the former socialist countries accepted in the EU in the Eastern enlargements of the Union in 2004 and 2007. As a counterimage to this threat, Europe is signified with order and wealth.

\section{Discussion and Conclusions}

Europe is a profoundly flexible concept, which can be filled with various meanings depending on the speaker's political aims. The meanings of Europe are not only different in different political discourses, but they are also 'floating' within a discourse. As the investigation indicates, the discursive construction of Europe in the party newspaper Perussuomalainen takes place through the framing of its dichotomic opponents (whether class-based, economic, political, cultural, religious, spatial, social, or historical) and defending the fluid and situationally transforming 'common people' against their threat. In populist discourse, Europe is given diverse and even contradictory meanings. On the one hand, Europe can be perceived as a cultural and value-based community that shares a common heritage, (Christian) traditions, and similar moral norms and values. In the discourse, identification with Europe and the promotion of European communality is particularly pronounced when a threat towards 'us' is experienced as coming from outside the imagined European borders. On the other hand, Europe as a political project and the political and cultural integration in Europe can be articulated as a threat to national independence, identity, and cultural particularity. When Europe is perceived as facing an extra-European threat, Europeanness is articulated as a 'thick' identity based on essentialist cultural features. When the threat is located within Europe or considered to be the EU, Europeanness loses its basis as a 
collective identity and transforms into a negation of a 'thick' essentialist national identity.

In the populist discourse, the idea of culture is actively taken into the political discussion. The notion of culture in the discourse emphasizes monoculturalism, 'purity' of cultural features, and one-layeredness of cultural identities. In the discourse, 'borderlessness' and the transformation of the current cultural, symbolic, and societal borders is often objected to or perceived as a threat to the 'right' or traditional order.

Europe is a 'floating signifier' which can be connected to various populist themes of protest, such as anti-elitism, anti-capitalism, anti-neoliberalism, antiintellectualism, anti-establishmentarianism, criticism towards multiculturalism, demands for increasing direct democracy, criticism of current political practices, etc. ${ }^{39}$ On the one hand, the 'floating' meanings of Europe in the populist discourse can be interpreted as indications of the disintegration and obscurity of the views on the populist political agenda. On the other hand, the floating nature of meanings can be used in the populist discourse as a political strategy to locate the threats outside the imagined 'us' and to project the fears of 'others' on a common 'scapegoat': the EU-Europe.

\section{Notes}

${ }^{1}$ Ulf Hannerz, Cultural Complexity (New York: Columbia University Press, 1992); Stuart Hall, 'New Cultures for the Old,' A Place in the World, eds. Doreen Massey and Pat Jess (Oxford: Oxford University Press, 1995), 175-213.

${ }^{2}$ Cris Shore, 'Ethnicity, Xenophobia and the Boundaries of Europe,' International Journal on Minority and Group Rights 4.3-4(1997): 247-262; Umut Özkirimli, Contemporary Debates on Nationalism: A Critical Engagement (New York: Palgrave Macmillan, 2005); Marcus Banks and André Gingrich, 'Neo-Nationalism in Europe and Beyond,' Neo-Nationalism in Europe and Beyond: Perspectives from Social Anthropology, eds. Marcus Banks and André Gingrich (Oxford: Berghahn Books, 2006), 1-26.

${ }^{3}$ John McCormick, Europeanism (Oxford: Oxford University Press, 2010).

${ }^{4}$ Jürgen Habermas, The Postnational Constellation: Political Essays (Cambridge: Polity Press, 2001).

${ }^{5}$ Chantal Mouffe, 'The End of Politics and the Rise of the Radical Right,' Dissent 42.4(1995): 498; Chantal Mouffe, On the Political (London: Routledge, 2005), chapter 4.

${ }^{6}$ Mouffe, On the Political.

${ }^{7}$ Slavoj Žižek, 'Why We All Love to Hate Haider,' New Left Review 2 (2000): 3739.

${ }^{8}$ Mouffe, On the Political. 
${ }^{9}$ Rauli Mickelsson, 'Suomalaisten nationalistipopulistien ideologiat,' Populismi: Kriittinen arvio, ed. Matti Wiberg (Helsinki: Edita, 2011), 147-174.

10 Tapio Raunio, 'Hesitant Voters, Committed Elite: Explaining the Lack of Eurosceptic Parties in Finland,' Journal of European Integration 27.4 (2005): 381395.

${ }^{11}$ Tuukka Ylä-Anttila, 'What is Finnish about the Finns Party? Political Culture and Populism' (Master's thesis, University of Helsinki, 2012); Ville Pernaa, et al., 'Median vaaliagenda ja jytky,' Jytky: Eduskuntavaalien 2011 mediajulkisuus, eds. Ville Pernaa and Erkka Railo (Turku: Kirja-Aurora, 2012), 396-410.

${ }^{12}$ Cas Mudde, 'The Populist Zeitgeist,' Government and Opposition 39.4 (2004): 541-563.

${ }^{13}$ Kurt Weyland, 'Clarifying a Contested Concept: Populism in the Study of Latin Americal Politics,' Comparative Politics 34.1 (2001): 1-22.

14 Robert Jansen, 'Populist Mobilization. A New Theoretical Approach to Populism,' Sociological Theory 29.2 (2011): 75-96.

${ }^{15}$ Ernesto Laclau, On Populist Reason (London: Verso, 2005).

${ }^{16}$ E.g., Gianfranco Pasquino, 'Populism and Democracy,' Twenty-First Century Populism. The Spectre of Western European Democracy, eds. Daniele Albertazzi and Duncan McDonnell (Hampshire: Palgrave MacMillan, 2008), 15-29; Laclau, On Populist Reason.

${ }^{17}$ Agnes Akkerman, Cas Mudde and Andrej Zaslove, 'How Populist Are the People? Measuring Populist Attitudes in Voters,' Comparative Political Studies, np, article first published online: 17 December 2013, viewed on 9 January 2014, http://cps.sagepub.com/content/early/2013/12/26/0010414013512600.full.

${ }_{18}$ Agnes Akkerman, Cas Mudde and Andrej Zaslove, 'How Populist Are the People?'; Cas Mudde, Populist Radical Right Parties in Europe (Cambridge: Cambridge University Press, 2007), 23.

${ }^{19}$ Agnes Akkerman, Cas Mudde and Andrej Zaslove, 'How Populist Are the People?'; Andrej Zaslove, 'Here to Stay? Populism as a New Party Type,' European Review 16.3 (2008): 319-336.

${ }^{20}$ Laclau, On Populist Reason.

${ }^{21}$ Laurent Thévenot, 'Oikeuttavuuden rajat. Yhteiselämää koossapitävät sidokset ja niiden väärinkäyttö,' trans. Veikko Eranti, Sosiologia 48.1 (2011a): 7-21; Laurent Thévenot, 'Power and Oppression from the Perspective of the Sociological Engagements: A Comparison with Bourdieu's and Dewey's Critical Approaches to Practical Activities,' Irish Journal of Sociology 19.1 (2011b): 35-67.

${ }^{22}$ E.g., Dennis Westlind, 'The Politics of Popular Identity: Understanding Recent Populist Movements in Sweden and the United States,' Lund Political Studies 89 (1996): 31-32. 
${ }^{23}$ Margaret Canovan, 'Trust the People! Populism and Two the Faces of Democracy,' Political Studies 47.1 (1999): 5.

${ }^{24}$ Daniele Albertazzi and Duncan MacDonnell, 'Introduction: The Sceptre and the Spectre,' Twenty-First Century Populism. The Spectre of Western European Democracy, eds. Daniele Albertazzi and Duncan McDonnell (Hampshire: Palgrave MacMillan, 2008), 6.

${ }^{25}$ Ernesto Laclau and Chantal Mouffe, Hegemony and Socialist Strategy: Towards a Radical Democratic Politics (London: Verso, 2011); see also David Howarth and Yannis Stavrakakis, 'Introducing Discourse Theory and Political Analysis,' Discourse Theory and Political Analysis: Identities, Hegemonies and Social Change, ed. David Howarth, Aletta Norval and Yannis Stavrakakis (Manchester: Manchester University Press, 2000), 1-24.

${ }^{26}$ E.g., Ernesto Laclau, 'Politics and the Limits of Modernity,' Social Text 21(1989): 70-71; Laclau, On Populist Reason, 133.

${ }^{27}$ Lynn Worsham and Gary A. Olson, 'Hegemony and the Future of Democracy: Ernesto Laclau's Political Philosphy,' Journal of Advanced Composition 19.1 (1999): 1-2.

${ }^{28}$ E.g., Thomas Diez, 'Speaking 'Europe': The Politics of Integration Discourse,' Journal of European Public Policy 6.4 (1999): 598-613; Thomas Christiansen, Knud Erik Jorgensen and Antje Wiener, eds. The Social Construction of Europe (London: Sage Publications, 2001); Thomas Risse, 'Social Constructivism and European Integration', European Integration Theory, eds. Thomas Diez and Antje Wiener (Oxford: Oxford University Press, 2004), 159-176.

${ }^{29}$ E.g., Monica Sassatelli, Becoming Europeans: Cultural Identity and Cultural Policies (New York: Palgrave Macmillan, 2009); Tuuli Lähdesmäki, 'Rhetoric of Unity and Cultural Diversity in the Making of European Cultural Identity,' International Journal of Cultural Policy 18.1 (2012): 59-75.

${ }^{30}$ On 'thick' and 'thin' identities see e.g., Gerard Delanty, 'Is There a European Identity?’ Global Dialogue 5:3-4 (2003): np, viewed on 9 January 2014, http://www.worlddialogue.org/content.php?id=269; Barrie Axford, 'The Dialectic of Borders and Networks in Europe: Reviewing "Topological Presuppositions”,' Comparative European Politics 4.2 (2006): 160-182.; Anna C. Davidson, 'Through Thick and Thin: 'European Identification for a Justified and Legitimate European Union,' Journal of Contemporary European Research 4.1 (2008): 32-47.

${ }^{31}$ Gerard Delanty, 'Social Integration and Europeanization: The Myth of Cultural Cohesion,' Yearbook of European Studies 14 (2000): 234.

${ }^{32}$ Vivienne Orchard, 'Culture as Opposed to What? Cultural Belonging in the Context of National and European Identity,' European Journal of Social Theory 5.4 (2002): 429.

${ }^{33}$ Ibid., 429-430. 
${ }^{34}$ Monica Sassatelli, 'Imagined Europe,' European Journal of Social Theory 5.4 (2002): 440.

35 Anders Hellström, 'Bringing Europe down to Earth,' Lund Political Studies 144 (2006): 54.

${ }^{36}$ Heikki Mikkeli, Euroopan idea: Eurooppa-aatteen ja eurooppalaisuuden pitkä historia (Helsinki: Finnish Historical Society, 1994), 188-189.

${ }^{37}$ E.g., Cris Shore, Building Europe: The Cultural Politics of European Integration (London: Routledge, 2000); Hellström, Bringing Europe down to Earth.

${ }^{38}$ Ole Wæver, 'European Security Identities,' Journal of Common Market Studies 34.1 (1996), 103-132; Hellström, Bringing Europe down to Earth, 182-183.

39 Ilkka Ruostesaari, 'Populistiset piirteet vennamolais-soinilaisen puolueen ohjelmissa’, Populismi: Kriittinen arvio, ed. Matti Wiberg (Helsinki: Edita, 2011), 106-107.

\section{Bibliography}

Akkerman, Agnes, Cas Mudde and Andrej Zaslove. 'How Populist Are the People? Measuring Populist Attitudes in Voters.' Comparative Political Studies, np. Article first published online: 17 December 2013 DOI: 10.1177/0010414013512600. Viewed on 9 January 2014. http://cps.sagepub.com/content/early/2013/12/26/0010414013512600.full.

Albertazzi, Daniele and Duncan MacDonnell. 'Introduction: The Sceptre and the Spectre.' Twenty-First Century Populism: The Spectre of Western European Democracy, edited by Daniele Albertazzi and Duncan McDonnell, 1-11. Hampshire: Palgrave MacMillan, 2008.

Axford, Barrie. 'The Dialectic of Borders and Networks in Europe: Reviewing “Topological Presuppositions”.' Comparative European Politics 4.2 (2006): 160182.

Banks, Marcus and André Gingrich. 'Neo-Nationalism in Europe and Beyond.' Neo-Nationalism in Europe and Beyond: Perspectives from Social Anthropology, edited by Marcus Banks and André Gingrich, 1-26. Oxford: Berghahn Books, 2006.

Canovan, Margaret. 'Trust the People! Populism and Two the Faces of Democracy.’ Political Studies 47.1 (1999): 2-16. 
Christiansen, Thomas, Knud Erik Jorgensen and Antje Wiener, eds. The Social Construction of Europe. London: Sage Publications, 2001.

Davidson, Anna C. 'Through Thick and Thin: European Identification for a Justified and Legitimate European Union.' Journal of Contemporary European Research 4.1 (2008): 32-47.

Delanty, Gerard. 'Social Integration and Europeanization: The Myth of Cultural Cohesion.' Yearbook of European Studies 14 (2000): 221-238.

Delanty, Gerard. 'Is There a European Identity?' Global Dialogue 5:3-4 (2003): np. Viewed on 9 January 2014. http://www.worlddialogue.org/content.php?id=269.

Diez, Thomas. 'Speaking Europe: The Politics of Integration Discourse.' Journal of European Public Policy 6.4 (1999): 598-613.

Habermas, Jürgen. The Postnational Constellation: Political Essays. Cambridge: Polity Press, 2001.

Hall, Stuart. 'New Cultures for the Old.' A Place in the World, edited by Doreen Massey and Pat Jess, 175-213. Oxford: Oxford University Press, 1995.

Hannerz, Ulf. Cultural Complexity. New York: Columbia University Press, 1992.

Hellström, Anders. 'Bringing Europe down to Earth.' Lund Political Studies 144. (2006).

Howarth, David and Yannis Stavrakakis. 'Introducing Discourse Theory and Political Analysis.' Discourse Theory and Political Analysis: Identities, Hegemonies and Social Change, edited by David Howarth, Aletta Norval and Yannis Stavrakakis, 1-24. Manchester: Manchester University Press, 2000.

Jansen, Robert. 'Populist Mobilization. A New Theoretical Approach to Populism.' Sociological Theory 29.2 (2011): 75-96.

Laclau, Ernesto. 'Politics and the Limits of Modernity.' Social Text 21 (1989): 6382.

Laclau, Ernesto. On Populist Reason. London: Verso, 2005. 
Laclau Ernesto and Chantal Mouffe. Hegemony and Socialist Strategy: Towards a Radical Democratic Politics. London: Verso, 2011.

Lähdesmäki, Tuuli. 'Rhetoric of Unity and Cultural Diversity in the Making of European Cultural Identity.' International Journal of Cultural Policy 18.1 (2012): 59-75.

McCormick, John. Europeanism. Oxford: Oxford University Press, 2010.

Mickelsson, Rauli. 'Suomalaisten nationalistipopulistien ideologiat.' Populismi: Kriittinen arvio, edited by Matti Wiberg, 147-174. Helsinki: Edita, 2011.

Mikkeli, Heikki. Euroopan idea. Eurooppa-aatteen ja eurooppalaisuuden pitkä historia. Helsinki: Finnish Historical Society, 1994.

Mudde, Cas. 'The Populist Zeitgeist.' Government and Opposition 39.4 (2004): 541-563.

Mudde, Cas. Populist Radical Right Parties in Europe. Cambridge: Cambridge University Press, 2007.

Mouffe, Chantal. 'The End of Politics and the Rise of the Radical Right.' Dissent 42.4 (1995): 498-502.

Mouffe, Chantal. On the Political. London: Routledge, 2005.

Orchard, Vivienne. 'Culture as Opposed to What? Cultural Belonging in the Context of National and European Identity.' European Journal of Social Theory, 5.4 (2002): 419-433.

Özkirimli, Umut. Contemporary Debates on Nationalism: A Critical Engagement. New York: Palgrave Macmillan, 2005.

Pasquino, Gianfranco. 'Populism and Democracy.' Twenty-First Century Populism: The Spectre of Western European Democracy, edited by Daniele Albertazzi and Duncan McDonnell, 15-29. Hampshire: Palgrave MacMillan, 2008.

Pernaa, Ville, Niko Hatakka, Mari K. Niemi, Ville Pitkänen, Erkka Railo and Matti Välimäki. 'Median vaaliagenda ja jytky.' Jytky: Eduskuntavaalien 2011 
mediajulkisuus, edited by Ville Pernaa and Erkka Railo, 396-410. Turku: KirjaAurora, 2012.

Raunio, Tapio. 'Hesitant Voters, Committed Elite: Explaining the Lack of Eurosceptic Parties in Finland.' Journal of European Integration 27.4 (2005): 381395.

Risse, Thomas. 'Social Constructivism and European Integration.' European Integration Theory, edited by Thomas Diez and Antje Wiener, 159-176. Oxford: Oxford University Press, 2004.

Ruostesaari, Ilkka. 'Populistiset piirteet vennamolais-soinilaisen puolueen ohjelmissa.' Populismi: Kriittinen arvio, edited by Matti Wiberg, 94-146. Helsinki: Edita, 2011.

Sassatelli, Monica. 'Imagined Europe.' European Journal of Social Theory 5.4 (2002): 435-451.

Sassatelli, Monica. Becoming Europeans. Cultural Identity and Cultural Policies. New York: Palgrave Macmillan, 2009.

Shore, Cris. 'Ethnicity, Xenophobia and the Boundaries of Europe.' International Journal on Minority and Group Rights 4.3-4 (1997): 247-262.

Shore, Cris. Building Europe: The Cultural Politics of European Integration. London: Routledge, 2000.

Thévenot, Laurent. 'Oikeuttavuuden rajat. Yhteiselämää koossapitävät sidokset ja niiden väärinkäyttö.’ Translated by Veikko Eranti. Sosiologia 48.1 (2011a): 7-21.

Thévenot, Laurent. 'Power and Oppression from the Perspective of the Sociological Engagements: A Comparison with Bourdieu's and Dewey's Critical Approaches to Practical Activities.' Irish Journal of Sociology 19.1 (2011b): 3567.

Wæver, Ole. 'European Security Identities.' Journal of Common Market Studies 34.1 (1996): 103-132.

Westlind, Dennis. 'The Politics of Popular Identity: Understanding Recent Populist Movements in Sweden and the United States.' Lund Political Studies 89 (1996). 
Weyland, Kurt. 'Clarifying a Contested Concept: Populism in the Study of Latin American Politics.' Comparative Politics 34.1 (2001): 1-22.

Worsham, Lynn and Gary A. Olson. 'Hegemony and the Future of Democracy: Ernesto Laclau's Political Philosphy.' Journal of Advanced Composition 19.1 (1999): 1-34.

Ylä-Anttila, Tuukka. 'What is Finnish about the Finns Party? Political Culture and Populism.' Master's Thesis, University of Helsinki, 2012.

Zaslove, Andrej. 'Here to Stay? Populism as a New Party Type.' European Review 16.3 (2008): 319-336.

Žižek, Slavoj. 'Why We All Love to Hate Haider.' New Left Review 2 (2000): 3746.

Tuuli Lähdesmäki, PhD, is a Senior Researcher at the Department of Art and Culture Studies in the University of Jyväskylä, Finland. She conducts her research on the discursive meaning-making of Europe and European identity in the research project, 'Populism as movement and rhetoric' (SA21000019101) funded by the Academy of Finland. 